\title{
Diverse Responses of Exotic Birds to Urbanization
}

\author{
Lawrence Edwin Conole*
}

School of Geography and Environmental Studies, University of Tasmania, Tasmania, Australia

\begin{abstract}
Exotic bird species are prominent members of urban avifaunas in many areas of the world, and much has been generalized about their distribution, abundance and undesirability in urban habitats. Less attention has been given to the spatial and functional responses of exotics to the urban environment. This study tests the hypothesis that exotic birds exhibit responses to environmental factors that are similar to those of local native birds. Exotics group with natives in generalist urban tolerant and specialized urban avoider assemblages, and their species richness and site similarity are broadly proportional with those of natives. Urban tolerant exotics are significantly larger than avoiders, as with native birds. Habitat filtering is occurring to create unique urban bird assemblages, acting differentially on all species according to their ecology and biology, regardless of origin.
\end{abstract}

Key words: Urban, Exotic, Birds, Spatial Distribution, Functional Responses.

\section{Introduction}

Exotic bird species are prominent members of urban avifaunas in many areas of the world (Blair 2001). An exotic species is defined as one that has established a reproductive population in an area not part of its natural range (Long 1981); the 'passive colonists' of Catterall (2009). Exotic bird species do not always establish self-sustaining populations in the locations to which they are introduced, despite sometimes considerable support and repeated attempts; they also suffer extinctions as well as going on to establish in new locations (Long 1981). Most exotic species also have extensive non-urban distributions in countries of introduction (Long 1981), and are not exclusively synanthropic.

Much has been generalized about the distribution, abundance and undesirability of exotic birds in general, including in urban habitats, particularly in the popular literature (Rolls 1969; Low 2002). For instance, it has been asserted that they reduce food production, compete with native species for resources and disperse invasive plants (Long 1981; Hart \& Bomford 2006). Despite a bad press, little empirical research has been published which specifically targets the effects of exotic birds in urban systems (Chace \& Walsh 2006; White et al. 2009), or their responses to environmental or habitat factors. In one of the few relevant studies, direct negative impacts of the Common Myna (Sturnus tristis) on native birds through competition for nest sites have

\footnotetext{
*Send correspondence to: Lawrence Edwin Conole School of Geography and Environmental Studies, University of Tasmania,

Private Bag 72, Sandy Bay, Tasmania 7002, Australia

E-mail:1conole@gmail.com
}

been demonstrated in Australia (Pell \& Tidemann 1997), though the same species' foraging strategy was found not to overlap with native species (Crisp \& Lill 2006). Recher (2006) suggested that most exotic birds in urban habitats are essentially benign, and are cherished by many city dwellers for '... colour, movement and song ...' in otherwise bland urban landscapes.

By their very presence, exotic species homogenize global urban avifaunas (McKinney 2006), but their distributions may not be homogeneous within cities (Natuhara \& Hashimoto 2009). Exotic species are often present in urban native vegetation remnants, but at lower levels of abundance than in surrounding built-up areas (Catterall 2009; Antos et al. 2006). Global 'ubiquitists' were found only to dominate 'bare' suburbs in subtropical Brisbane (Catterall 2009), and the same is true for temperate Melbourne (Conole \& Kirkpatrick 2011) and many other cities (e.g. Hugo \& Van Rensburg 2009; Croci et al. 2008; van Heezik et al. 2008; Kark et al. 2007; Chace \& Walsh 2006). In studies of the distributions of plants it has been common to find that exotic species are as closely related to environmental variation as native plants (e.g. Fensham \& Kirkpatrick 1989; McKinney 2004).

There have been assumptions made more widely that as many exotic bird species are at least in part synanthropic (Johnston 2001), that this conveys a competitive advantage in urban environments. An unstated assumption of this generalization is that exotic bird species introduced into urban habitats will be free of the environmental constraints operating on the range of formerly occurring and colonizing 
native bird species. The distributions of native and exotic birds in Melbourne are intermixed (Conole \& Kirkpatrick 2011), suggesting that any presumed freedom from urban environmental constraints for exotics may be in error at least for this city, and therefore worthy of exploration.

At the time of writing, Melbourne had 13 established non-native bird species present within its terrestrial bird assemblages (Conole \& Kirkpatrick 2011). Most species are long established in Melbourne, having been introduced since the mid to late nineteenth century. This well-established and diverse exotic avifauna has parallels elsewhere in the temperate zones of the world, particularly in New Zealand, Western Europe and North America (Long 1981).

In this paper the hypothesis is advanced that exotic and native urban tolerant species are similar in their range of spatial and functional responses to urbanization; in other words, environmental filters operating on the natives will also act on exotics. As subsets of the main hypothesis it is theorized that i) most exotic species will be urban tolerant, but some more specialized species will be urban avoiders; ii) exotic species diversity will vary proportionally with overall bird species diversity; and, iii) most exotic species will be least abundant in areas of low urbanization intensity and higher native species richness.

\section{Material and Methods}

Detailed descriptions of the study area and methodology used to derive the urban bird assemblages can be found in the Supplementary Material ${ }^{*}$, and in Conole \& Kirkpatrick (2011). A brief summary follows below.

\section{Study area and data handling}

The study area is metropolitan Melbourne; capital city of the State of Victoria in coastal south-eastern Australia, within a $50 \mathrm{~km}$ radius of its Central Business District ( $37^{\circ} 49^{\prime} \mathrm{S}$ and $144^{\circ} 58^{\prime}$ E). Approximately 220,000 records of birds were extracted from the Birds Australia 'New Atlas of Australian Birds' project database and intersected with $1 \times 1 \mathrm{~km}$ grid (Hahs \& McDonnell 2007) to produce a matrix of grid cells by species presence/absence. Species and sites were filtered out according to criteria for representativeness to arrive at a final list of 141 species and 390 cells (Figure 1).

\section{Environmental and demographic indices}

Index $_{\text {combined }}$, representing urbanization intensity by a combination of demographic and spatial data; is derived from Index image $_{\text {a }}=$ spectral mixture analysis of the 2000 Landsat ETM+ image, and Index $x_{\text {census }}=$ the total number of people multiplied by the proportion of males employed in non-agricultural work (Hahs \& McDonnell 2006).

\section{Data analysis}

A Bray-Curtis distance matrix was prepared, and groups of species (assemblages) were formed by hierarchical

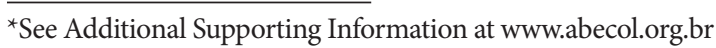

agglomerative clustering using Ward's algorithm performed on the distance matrix, as a function of their similarity in distribution and relative abundance (Conole \& Kirkpatrick 2011). Jaccard's Index of similarity was calculated for exotic $\left(J I_{\text {exotic }}\right)$ and native $\left(J I_{\text {native }}\right)$ species by site (390 sites, 75844 pairwise comparisons). A ratio ( $\left.J I_{\text {exotic }} / J I_{\text {native }}\right)$ served as a relative metric indicating whether grid cells showed a tendency to share exotic species to a greater (ratio $>1$ ) or lesser extent (ratio < 1) than native species (McKinney 2004).

\section{Results}

Species richness of exotic birds in Melbourne is proportional to total bird species richness $\left(R^{2}=0.213\right)$ (Figure 2). The Jaccard's Index of similarity among sites for exotic and native species $\left(R^{2}=0.187\right)$ (Figure 2$)$ follows the species richness trend; in other words, sites that share many native species also share many exotic species, and vice versa. However, relative abundance (incidence in surveys) of individual exotic species is broadly inversely proportional to native bird species richness (Figures 3, S2). In all cases the Jaccard's Index ratio between exotic and native birds exceeded one $(>1)$.

Melbourne has 13 established exotic bird species present within its terrestrial bird assemblages (excluding waterbirds). All non-Australian species are from the Old World; either Eurasian or S-SE Asian in origin (Long 1981). Of the 13 species, eight are urban exploiters distributed widely in the urban area and either universally or locally abundant (Conole \& Kirkpatrick 2011) (Table 1). The other five species are urban avoiders, and are either habitat or foraging specialists abundant only in non-urbanised habitats, or are rare with localized occurrences (Conole \& Kirkpatrick 2011) (Table 1).

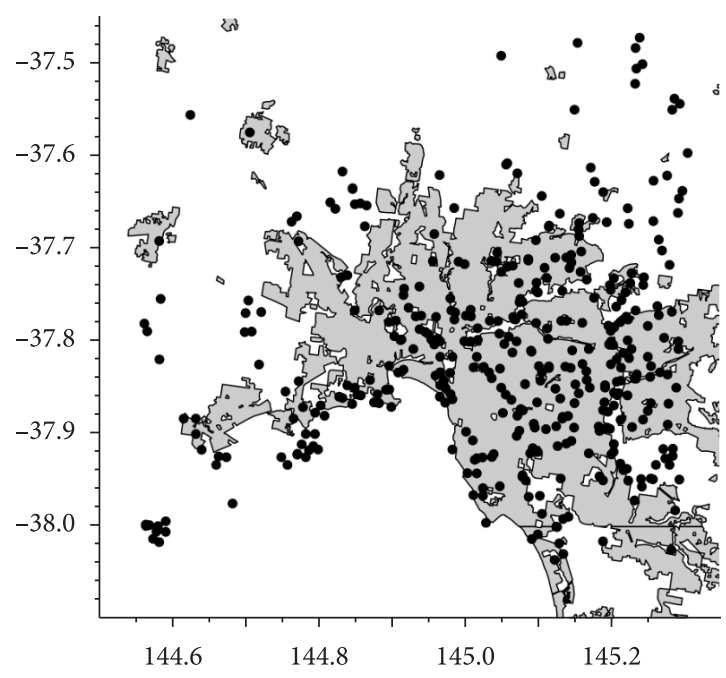

Figure 1. Spatial plot of filtered grid cells (black circles) over the Melbourne study area (built-up areas shaded grey) ( $\mathrm{x}=$ longitude, $\mathrm{y}=$ latitude; decimal degrees). 

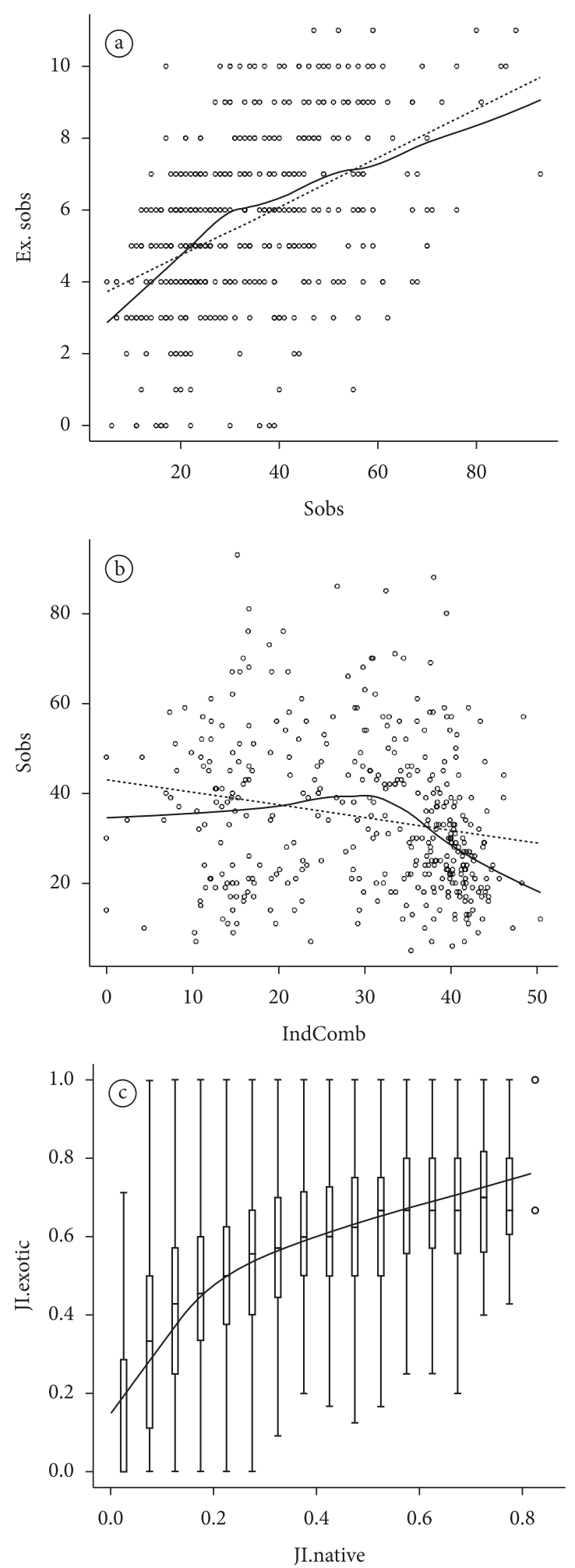

Figure 2. a) Exotic bird species richness $\left(S_{\text {extic }}\right)$ (y axis) plotted as a function of total bird species richness $\left(S_{\text {obs }}\right)(\mathrm{x}$ axis $)\left(\mathrm{R}^{2}=0.213\right)$. Regression line and Lowess curve shown; b) All bird species richness $\left(S_{o b s}\right)$ plotted as a function of a measure of urbanization intensity (IndComb). $\left(\mathrm{R}^{2}=0.037\right)$. Regression line and Lowess curve shown; c) Jaccard's Index $\left(J I_{\text {exotic }}\right)$ for exotic bird species shared between sites (y axis), plotted against Jaccard's Index $\left(J I_{\text {native }}\right)$ for all native species ( $\mathrm{x}$ axis) $\left(\mathrm{R}^{2}=0.187\right)$. Lowess curve shown.
The most widespread species, occurring at over $80 \%$ of the 390 grid cells, were respectively Common Myna, Common Blackbird, Common Starling and Spotted Dove (Table 1). The incidence in surveys of these species is proportional to urbanization intensity (Figure 3, S1). The other nine species occurred in $1.8-62.1 \%$ of sites (Table 1 ).

The general trend for all exotics at the landscape scale is that they peak in relative abundance as a measure of

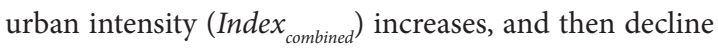
at the highest values of Index combined $($ e.g. Figure 2, S1). The corollary of this is that individual exotic species relative abundance declines as overall bird species richness increases (Figure 3, S2). In other words, exotics are least diverse in areas that are least urbanised and with greater diversity of all bird species.

Following the patterns established earlier for the entire urban avifauna (Conole \& Kirkpatrick 2011), body mass of urban exploiters amongst the exotic birds is significantly greater than for urban avoiders (Student's $t$-test: $\mathrm{p}=0.033$ ) (Figure 4). Likewise, the only ground-nesting, frugivorous and nectarivorous exotics are urban avoiders (Table 1).

\section{Discussion}

It has already been demonstrated in earlier work that most exotic species in Melbourne are urban tolerant (Green 1986), but this is not universal, and some more specialized species are urban avoiders: Eurasian Skylark, Common Greenfinch, European Goldfinch, Red-whiskered Bulbul and Scaly-breasted Lorikeet (Conole \& Kirkpatrick 2011). The first three exotic species fit with a suite of native bird species which characterize the assemblage as one largely of coastal areas, grassland, and wetland margins, whilst the latter two fit with the range of rare and range-restricted species in the largest of Melbourne's urban bird assemblages (Conole \& Kirkpatrick 2011). The remaining eight species are classic urban exploiters, being widespread and at times abundant in a range of more intensively urbanised sites (Conole \& Kirkpatrick 2011).

The sorting of exotic species into three of Melbourne's four urban bird assemblages, exhibiting similar functional and spatial responses to urbanization as for the natives, gives the first indication that both native and exotic species are filtered by habitats (Conole \& Kirkpatrick 2011). The size differential between urban exploiter and urban avoider exotic birds matches that in native urban birds (Figure 4), as do the nest substrate and foraging profiles (Table 1, this paper; Conole \& Kirkpatrick 2011).

The results of investigations conducted for the present paper indicate that exotic species richness and the extent to which sites share exotic species, are broadly proportional with those same variables in native urban birds. In the case of individual species trends, it is also clear that there are several responses at the highest level of urban intensity. Some species more typical of suburban habitats such as 


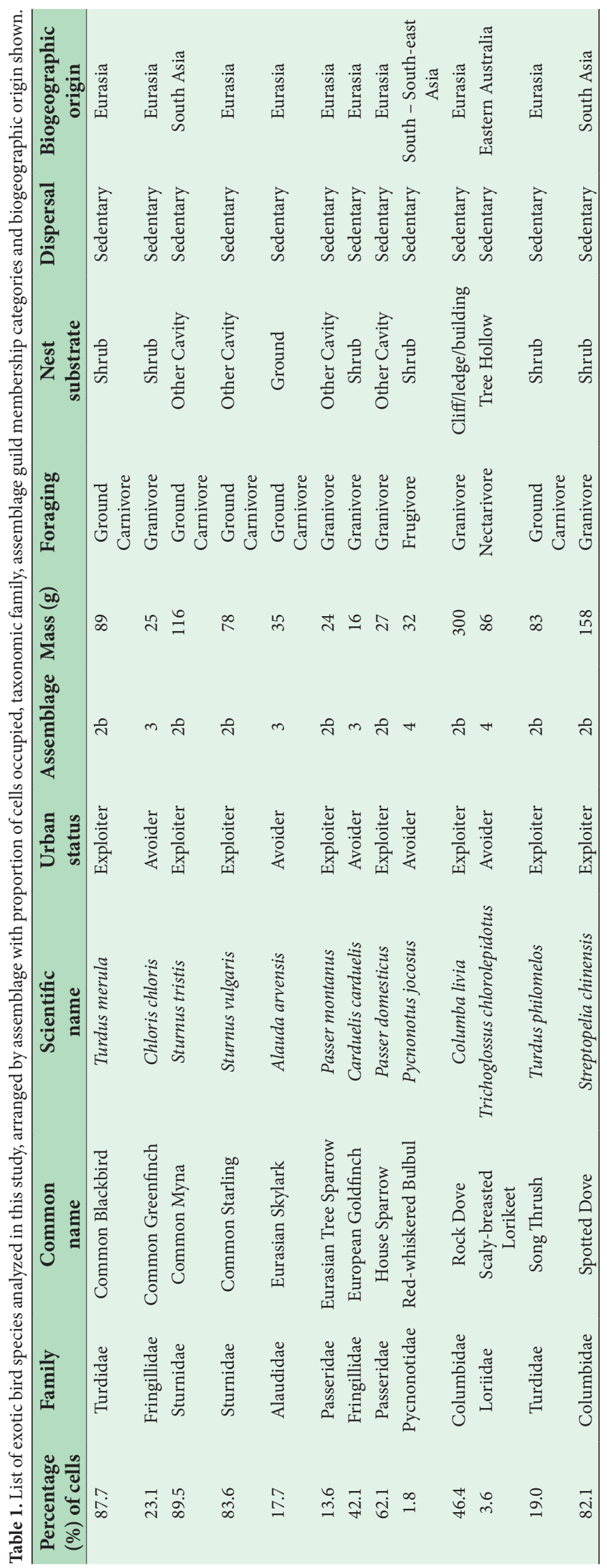



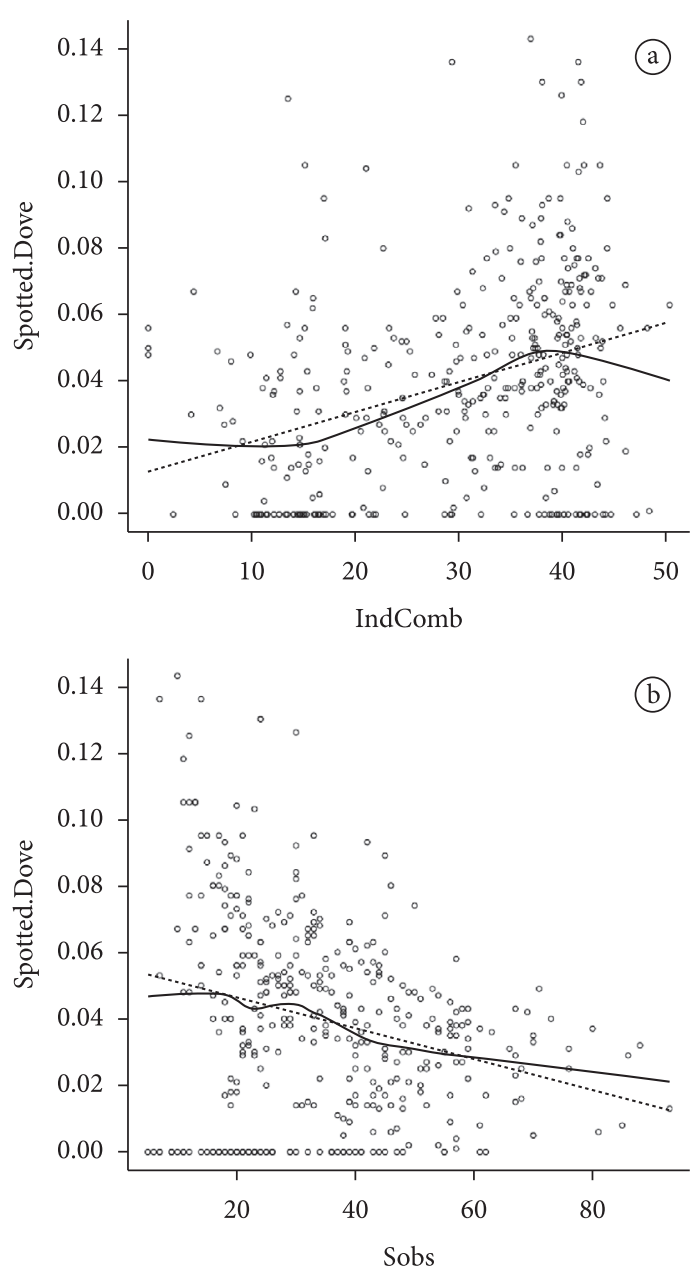

Figure 3. a) Spotted Dove incidence in surveys (y axis) plotted against a measure of urbanization intensity (Index combined $_{\text {) }}$ ( $\mathrm{x}$ axis) $\left(\mathrm{R}^{2}=0.117\right)$. Regression line and Lowess curve shown; b) Spotted Dove incidence in surveys (y axis) plotted against species richness of all birds $\left(S_{o b s}\right)(\mathrm{x}$ axis $)\left(\mathrm{R}^{2}=0.153\right)$. Regression line and Lowess curve shown.

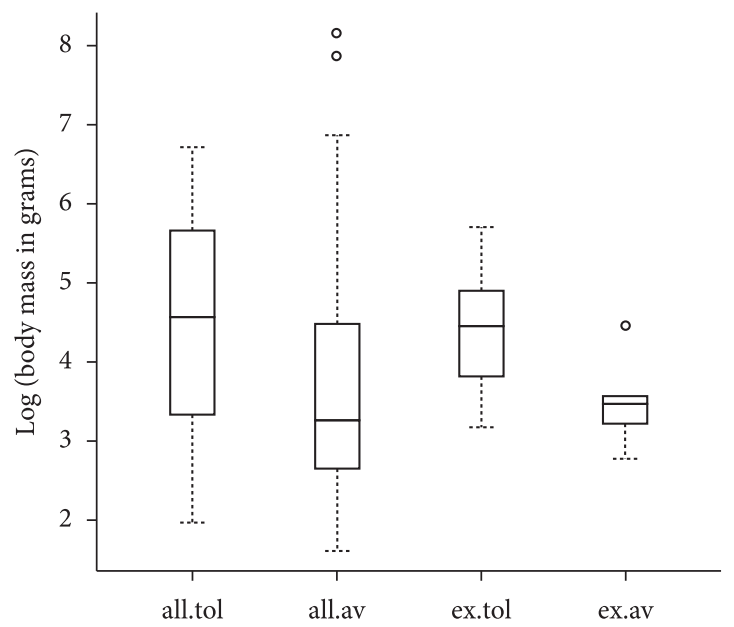

Figure 4. Body mass (g, log transformed) of urban tolerant and urban avoider birds in Melbourne, for all species (all.tol, all.av) and exotic species (ex.tol, ex.av). the Spotted Dove and Common Blackbird (Conole \& Kirkpatrick 2011) (Figures 3, S1) show a terminal decline in incidence, whereas more broadly based urban exploiters such as Common Myna, Common Starling and House Sparrow (Figure S1) show a terminal upward trend. There is not a generic response by exotic birds to urbanization intensity.

In all cases the Jaccard's Index ratio between exotics and natives was greater than one $\left(J I_{\text {exotic }} / J I_{\text {native }}>1\right)$, indicating that across all sites the tendency was for more sharing of exotic than native species, or that some exotics showed a tendency to be evenly distributed throughout the urban area. The hypothesis that environmental and other filters operating on the native avifauna also act on exotic species is compelling, based on these data.

Individual exotic bird species relative abundance shows a clear trend of decline for all species as total bird species richness $\left(S_{o b s}\right)$ rises (Figure S2). Most decline uniformly across the range of $S_{o b s}$, whilst others (Red-whiskered Bulbul, Scaly-breasted Lorikeet) decline from a mid-point to higher $S_{o b s}$, or are slightly bimodal (Common Blackbird, Common Starling and House Sparrow) (Figure S2). The Spotted Dove (Figure 3), Common Starling and House Sparrow (Figure S2) show a much flatter declining trend than other common exotic species, and this reflects the extent to which these species occur across the urban habitat spectrum, including the propensity to invade areas of higher native vegetation integrity with accompanying higher native bird $S_{o b s}$ (L.E. Conole, pers. obs.). These trends are broadly consistent with that observed by Antos et al. (2006), that exotic bird species were less abundant in native vegetation remnants than in surrounding suburbs in Melbourne, but not strongly for all species. The hypothesis subset that most exotic species reach their lowest relative abundance in areas of low urban intensity with high diversity of native birds is supported.

Biomass of exotic bird species often significantly exceeds that of native species in intensively urbanized habitats (Blair 2001), and examinations of species richness alone do not address this apparent imbalance. It is generally assumed that this imbalance is an adverse outcome of competition between exotic and native species. However, the conceptual model created from earlier work on these data (Conole \& Kirkpatrick 2011) and supported again here, suggests that it may also be possible that species-poor subsets of urban tolerant bird assemblages (including a small number of exotic and native species) prosper at sites that are at the extremes of urban habitat gradients. Such highly urbanised sites are species poor for both native and exotic bird species (Figure 2). Exotic bird dominance may therefore be a marker of particular urban habitat types where overall bird species richness and individual native species abundance is low (Figures 2 and 3).

The data and analyses presented here and by others (Conole \& Kirkpatrick 2011; Croci et al. 2008; Kark et al. 2007) suggest that habitat filtering is occurring to create unique 
urban bird assemblages, acting differentially on all species according to their ecological traits, regardless of whether they are exotic or native.

\section{Acknowledgements}

Jamie Kirkpatrick (University of Tasmania) provided insights and constructive criticism at all stages of this research. Andrew Silcocks and Mike Weston (Birds Australia) facilitated access to the Birds Australia Atlas II database. Amy Hahs (ARCUE) provided access to her dataset of remotely sensed landscape metrics. Database and GIS manipulations of the Birds Australia and ARCUE datasets were performed by Luke Cameron.

\section{References}

Antos MJ et al., 2006. Introduced birds in urban remnant vegetation: does remnant size really matter? Austral Ecology, 31:254-261. http://dx.doi. org/10.1111/j.1442-9993.2006.01572.x

Blair RB, 2001. Creating a homogenous avifauna. In: Marzluff JM, Bowman R \& Donnelly R (Eds.). Avian Ecology and Conservation in an Urbanizing World. Boston: Kluwer Academic Publishers. p. 457-486.

Catterall CP, 2009. Responses of faunal assemblages to urbanisation: global research paradigms and an avian case study. In: McDonnell MJ, Hahs AK \& Brueste JH (Eds.). Ecology of Cities and Towns: a Comparative Approach. Cambridge: Cambridge University Press. http://dx.doi. org/10.1017/CBO9780511609763.009

Chace J \& Walsh J, 2006. Urban effects on native avifauna: a review. Landscape and Urban Planning, 74: 46-69. http:// dx.doi.org/10.1016/j.landurbplan.2004.08.007

Conole LE \& Kirkpatrick JB, 2011. Functional and spatial differentiation of urban bird assemblages at the landscape scale. Landscape and Urban Planning, 100(1-2):11-23. http:// dx.doi.org/10.1016/j.landurbplan.2010.11.007

Crisp H \& Lill A, 2006. City slickers: habitat use and foraging in urban Common Mynas Acridotheres tristis. Corella, 30:9-15.

Croci S, Butet A \& Clergeau P, 2008. Does urbanization filter birds on the basis of their biological traits. Condor, 110:223-40. http://dx.doi.org/10.1525/cond.2008.8409

Fensham RJ \& Kirkpatrick JB, 1989. The conservation of original vegetation remnants in the Midlands, Tasmania. Proceedings of the Royal Society of Tasmania, 123:229-246.

Green RJ, 1986. Native and exotic birds in the suburban habitat. In: Ford HA \& Paton DC (Eds.). The Dynamic partnership: birds and plants in Southern Australia. Adelaide: The Flora and Fauna of South Australia Handbooks Committee.
Hahs AK \& McDonnell MJ, 2006. Selecting independent measures to quantify Melbourne's urban-rural gradient. Landscape and Urban Planning, 78:435-48. http://dx.doi. org/10.1016/j.landurbplan.2005.12.005

Hart Q \& Bomford M, 2006. Science for Decision Makers: Australia's Pest Animals, New Approaches to Old Problems. Canberra: Australian Government Bureau of Rural Sciences.

Hugo S \& Van Rensburg BJ, 2009. Alien and native birds in South Africa: patterns, processes and conservation. Biological Invasions, 11:2291-2302. http://dx.doi.org/10.1007/ s10530-008-9416-X

Johnston, RF, 2001. Synanthropic birds of North America. In: Marzluff JM, Bowman R \& Donnelly R (Eds.). Avian Ecology and Conservation in an Urbanizing World. Boston: Kluwer Academic Publishers. p. 49-67.

Kark S et al., 2007. Living in the city: can anyone become an 'urban exploiter'? Journal of Biogeography, 34:638-51. http:// dx.doi.org/10.1111/j.1365-2699.2006.01638.x

Long JL, 1981. Introduced birds of the world. Sydney: Reed.

Low T, 2002. Feral Future. Melbourne: Penguin.

McKinney ML, 2004. Do exotics homogenise or differentiate communities? Roles of sampling and exotic species richness. Biological Invasions, 6:495-502. http://dx.doi. org/10.1023/B:BINV.0000041562.31023.42

McKinney ML, 2006. Effects of urbanization on species richness: a review of plants and animals. Urban Ecosystems, 11:161-176. http://dx.doi.org/10.1007/s11252-007-0045-4

Natuhara Y \& Hashimoto H, 2009. Spatial pattern and process in urban animal communities. In: McDonnell MJ, Hahs AK \& Brueste JH (Eds.). Ecology of Cities and Towns: a Comparative Approach. Cambridge: Cambridge University Press. http://dx.doi.org/10.1017/CBO9780511609763.013

Pell A \& Tidemann C, 1997. The ecology of the common myna in urban nature reserves in the Australian Capital Territory. Emu, 97:141-9. http://dx.doi.org/10.1071/MU97018

Recher H, 2006. Invaders in the cities: terrorists or companions? In: Olsen P, A Silcocks \& M Weston (Eds.). The state of Australia's birds 2006: invasive species. Hawthorn East: Birds Australia. Available from: <http://www.birdsaustralia. com.au/images/stories/publications/soab/soab2006s.pdf>. Access in: 18 nov. 2010.

Rolls E, 1969. They all ran wild. Sydney: Angus \& Robertson.

Van Heezik Y, Smyth A \& Mathieu R, 2008. Diversity of native and exotic birds across an urban gradient in a New Zealand city. Landscape and Urban Planning, 87:223-232. http:// dx.doi.org/10.1016/j.landurbplan.2008.06.004

White JG et al., 2009. Surviving urbanisation: maintaining bird species diversity in urban Melbourne. The Victorian Naturalist, 126:73-8. 